\title{
Financial Regulation AND Performance: Cross-Country EVIDENCE
}

\author{
James R. Barth \\ Auburn University \\ Gerard Caprio, Jr. \\ The World Bank \\ Ross Levine \\ University of Minnesota
}

The unprecedented number of costly bank failures throughout the world in the last two decades of the twentieth century has focused attention on the need to determine more appropriate ways to improve the performance of countries' financial systems. Indeed, a substantial literature is already emerging on the causes and consequences of banking - crises and on various reforms that might help prevent future crises. ${ }^{1}$ Although the proposed reforms differ in important respects, nearly all include changes in existing financial regulations and supervisory standards. This core of agreement is certainly understandable, insofar as financial crises in countries ranging from the United States and Japan, to Korea and Mexico, to Chile and Thailand, to India and Russia, and to Ghana and Hungary have been blamed at least in part on "bad" regulation and supervision. Virginia.

At the time of writing, Ross Levine was affiliated with University of

The findings, interpretations, and conclusions expressed in this paper are entirely those of the authors and do not necessarily represent the views of the World Bank, its executive directors, or the countries they represent.

1. See, for example, Bank for International Settlements (1998); Barth and others (1998); Caprio (1998a); Demirgüç-Kunt and Detragiache (1997, 1998); García, Lindgren, and Saal (1996); Goldstein and Turner (1996); Goldstein (1998); and Radelet and Sachs (1998).

Banking, Financial Integration, and International Crises, edited by Leonardo Hernández and Klaus Schmidt-Hebbel, Santiago, Chile. (c) 2002 Central Bank of Chile. 
In response to this recent and troubling situation, the World Bank, the International Monetary Fund, and other international financial institutions are attempting to promote financial stability and economic development by more vigorously urging countries to adopt and then implement appropriate regulations and supervisory practices for their financial sectors. The World Bank, for instance, in virtually all its financial sector reviews and projects, now stresses more than ever the importance of prudential regulation and supervision. The overwhelmingly widespread belief is that many countries can significantly improve upon their existing financial systems, thereby reducing the likelihood of financial instability and facilitating long-run economic growth. More generally, the belief appears universal among those who have studied these issues that inappropriate regulations and supervisory standards not only retard a country's long-run rate of economic growth but also increase the likelihood of a financial crisis that could spread beyond the country's own borders.

Remarkably, however, despite all the agreement on the need for financial reform, there is relatively little empirical evidence to support any concrete advice regarding either specific or comprehensive regulatory and supervisory reforms. The reason for this awkward situation is that detailed cross-country comparisons of financial regulatory and supervisory systems for developing countries do not yet exist. ${ }^{2}$ Without such information, economists have nonetheless been able to conclude that incentives are critical in understanding the behavior of the different agents that comprise the financial sector. In this regard, it is now recognized that the moral hazard problem has become more widespread and hence explains in part the recent worldwide outbreak of banking crises. ${ }^{3}$ Economists have not yet been able to reach a conclusion, however, about the most appropriate way to correct the incentive and moral hazard problems facing banks, such as by requiring higher (and more narrowly defined) capital-to-asset ratios, mandating stricter definition and disclosure of nonperforming loans, requiring that subordinated debt be issued, or installing "worldclass" supervision.

2. Barth, Nolle, and Rice (1997) provide fairly detailed comparative information on bank regulatory and supervisory systems for nineteen countries: the Group of Ten (G-10) large industrial countries and the other members of the European Union. They provide relatively little analysis, however, of appropriate reforms for these systems.

3. More generally, the moral hazard problem, when not contained, gives rise to an inefficient allocation of resources. 
The inability to reach a conclusion about specific ways to resolve these serious problems is not surprising, given that data on the practices of various financial regulatory and supervisory authorities for a wide range of countries have not been assembled and analyzed. This lack of information is quite important because it means that current efforts to reform financial regulation and supervision are occurring without knowing whether or under what circumstances these efforts will be successful. One should realize, moreover, that in situations in which the salaries of supervisors are only 5 to 10 percent of those of the supervised, or in which individuals can easily move (and usually with ample financial gain) from careers as regulators to careers with the regulated firms, reform efforts are unlikely to be truly successful.

To characterize the lack of financial regulatory and supervisory data more concretely, even information on the extent to which banks in different developing countries are allowed to, and do, engage in various securities, insurance, and real estate activities has not yet been compiled and analyzed. Nor is there any systematic compilation and analysis of information, for a broad cross section of countries, on whether they allow banks to own or be owned by nonfinancial firms. Yet the extent to which these specific banking activities or banking and commerce interrelationships inhibit or promote the development of an efficient and stable financial system, or increase or decrease the likelihood of a banking crisis, is largely unknown without such information. In short, many important and pressing questions regarding the appropriate way to reform financial sector regulation and supervision in many countries throughout the world cannot today be adequately answered.

Research on these types of issues, therefore, is of critical importance because it will enable researchers to better identify the particular mix of regulations and supervisory standards that promotes well-functioning financial systems. With this identification, one would then be in a position to provide better guidance to policymakers on appropriate financial sector reforms. Ongoing research is already significantly improving our understanding of the broad relationships between the type of legal system existing within a country and its financial sector development. ${ }^{4}$ The somewhat narrower research discussed here complements this other work.

4. See La Porta and others (1997, 1998), Levine (1998), and Levine, Loayza, and Beck (2000). 
This paper focuses on the regulation and supervision of the banking sector. ${ }^{5}$ Efforts to collect detailed and comprehensive information on the different financial regulatory and supervisory environments that exist in the approximately 200 countries throughout the world are just beginning, and at present only partial information is available for about fifty countries. Given this situation, we make use of the information that is available. Fortunately, the recently obtained data include information on the degree to which regulatory restrictions are imposed on several important and even controversial activities of banks. This newer information, together with that previously gathered, enables us to examine empirically for the first time, albeit in a preliminary manner, the interrelationships among some important regulatory, governmental, and financial variables.

Specifically, the following three questions are examined-and briefly answered-in this paper:

- Do countries with relatively weak government or bureaucratic systems impose harsher regulatory restrictions on the activities of banks? We find that the answer to this question is yes.

- Do countries with more restrictive regulatory systems have poorly functioning banking systems? The evidence is mixed.

- Do countries with more restrictive regulatory systems have a lower probability of suffering a banking crisis? The answer is no. In fact, the results indicate that the opposite is the case: In countries in which the securities activities of banks are restricted, the likelihood of a banking crisis is greater, ceteris paribus.

The third finding contradicts those who believe that stricter restrictions on the allowable activities of banks constrains excessive risk-taking behavior, partly by making banks easier for both the supervisory authorities and market participants to monitor. ${ }^{6}$ Two forces may be at work to produce such a result. First, to the extent that more narrowly defined banking activities (such as making loans) and broader financial activities (such as securities and insurance

5. It should be noted, however, that in many developing and emerging market economies the banking sector is the most important component of the financial system.

6. In the case of the U.S. savings and loan debacle, despite the fact that unitary thrift holding companies had comparatively few restrictions on their activities, including the mixing of banking and commerce, these broader powers were not found to be a significant factor. See, for example, Barth (1996). 
activities) are not highly and positively correlated, banks in countries that allow broader powers are able to benefit by being more diversified in their operations. This reduces the likelihood of both failures and crises. ${ }^{7}$ Second, Hellmann, Murdoch, and Stiglitz (1998) demonstrate that, by imposing one specific restriction-deposit interest rate ceilings - on banks, a country may obtain a more robust banking system, mainly because of the resulting higher franchise value. Our findings, however, indicate that harsher restrictions on those banks' activities considered here are likely to lower franchise value, either by limiting profits (by reducing economies of scale and scope) or by increasing the variability of profits (by leaving average profits unchanged but reducing the market value of those profits to the extent that investors prefer less rather than more volatility). ${ }^{8}$ This means that reducing, if not totally eliminating, these restrictions would allow greater diversification and thereby enhance franchise value. This regulatory reform, in turn, would induce more incentive-compatible behavior on the part of banks. ${ }^{9}$ The gain from allowing broader banking powers appears to more than offset whatever added complications such a move toward "universal banking" would imply for monitoring. ${ }^{10}$

These empirical results, of course, are preliminary. A more extensive data set will be assembled to permit analysis of a wider variety of regulatory issues. An attempt will also be made to obtain indicators of the ability of supervisory authorities and market participants to monitor banks. The database, moreover, will be expanded beyond the fifty countries in our sample, thereby increasing the power of the empirical tests. For a discussion of data and additional analyses, see Barth, Caprio, and Levine (2001, a, b, c).

Despite the preliminary nature of these results, they do seem sufficiently robust that policymakers should consider them, along

7. See Caprio and Wilson (1997) for evidence identifying a link between a lack of diversification and bank failures in selected countries.

8. Bankers frequently lament that restrictions on their ability to engage in investment banking activities excludes them from more profitable lines of business. However, it should not be the case, at least in the long run, that one sector will have a consistently higher profit rate than another, other things equal. For this reason, the argument based on economies of scale and scope is more persuasive with respect to eliminating the restrictions.

9. Some argue, moreover, that bank ownership of nonfinancial firms may improve corporate governance.

10. From an empirical analysis, Puri (1996) concludes that universal banks are better than investment banks at underwriting securities. 
with the results of other recent work on banking crises, in deciding upon the most appropriate way in which to reform bank regulation. More specifically, this and other recent research suggests that several initial steps could be taken to reduce significantly the likelihood of banking crises. Countries could, among other things, develop and improve legal systems and information disclosure (see Demirgüç-Kunt and Detragiache, 1997, 1998); impose rate ceilings on bank deposits (Hellmann, Murdoch, and Stiglitz, 1998); establish limits either on the rate at which banks can expand credit or on the rate of increase in their exposure to certain sectors, such as real estate (see Caprio, Atiyas, and Hanson, 1994, and Barth and others, 1998); require greater diversification of bank portfolios (see Caprio and Wilson, 1997); and, on the basis of the results reported in this paper, reduce the restrictions on the range of activities in which banks can engage. Determining which combinations of these recommendations are most appropriate for individual countries at different stages of development should be the subject of future empirical research.

The remainder of the paper proceeds as follows. Section 1 reviews some of the recent literature on the relationship between bank regulation and supervision and banking sector performance, and the reasons why this relationship is the subject of considerable and sometimes heated debate. ${ }^{11}$ Section 2 essentially provides a progress report on the linkages that have been found between bank regulatory restrictiveness (or, more accurately, the degree to which there are limits on bank-allowable activities) and bank performance. Section 3 summarizes some issues to be addressed in future research.

\section{Regulation and Performance: Some Issues}

All the attention currently being given to the role of government in the financial sector-its participation as owner of financial intermediaries, its intervention in pricing and allocating credit, and its role in regulating and supervising financial intermediaries-is not surprising in view of recent events around the world. Yet for decades the size, composition, and functioning of the financial system were

11. In March 1997, for instance, U.S. House Banking Committee Chairman James Leach said that "Mixing commerce and banking simply doesn't fit our kind of democracy." See Barth, Brumbaugh, and Yago (1997, p. 47). 
generally considered to be unimportant for economic development and growth, and therefore usually omitted from standard macroeconomic models and development texts. ${ }^{12}$ This neglect of the financial system enabled governments more easily to use it for their own, sometimes relatively narrow, purposes. In many developing countries, for example, collecting taxes, issuing government debt at low cost, and allocating subsidized credit to accomplish various government goals were the primary tasks assigned to the financial system. The resulting, severe financial repression in countries that operated their financial systems in this way was a widely recognized sign of failure. The response was greater financial liberalization, beginning in the industrial countries and in a few developing countries in the 1970s (although in the former group the degree of financial repression had been negligible) and spreading more broadly in the 1980s and 1990s.

The trend toward more liberalized financial systems, however, has not been the only development. More than 130 countries have suffered from very costly episodes of banking problems in the past two decades, culminating in the financial crisis in East Asia in 199798. Indeed, the costs of resolving bank failures have amounted to 10, 20 , and even 30 percent of GDP in various countries in recent years. ${ }^{13}$ Current attention is focused mainly on Japan, where the nonperforming loans of banks in 1998 were estimated to be as high as $\$ 1$ trillion, with associated losses amounting to 40 to 50 percent of this figure, according to some press reports.

Given these recent and disturbing developments, it is quite understandable that the government's role with respect to the financial system is receiving unprecedented attention throughout the world. It has long been established that every government will be significantly involved in the money supply process and, in particular, in assigning lender-of-last-resort responsibilities to a central bank. ${ }^{14}$ The involvement of governments in the financial system in nearly all countries has expanded beyond these areas, however. Most recently, for example, governments in many countries have been establishing explicit deposit insurance schemes. Overwhelmingly, governments

12. Importantly for the focus of this paper, Freixas and Rochet (1998), state "that a microeconomic theory of banks could not exist before the foundations of the economics of information were laid [in the early 1970s]."

13. See Caprio and Klingebiel (1997, p. 80, and 1996, p. 15) and García, Lindgren, and Saal (1996, p. 30).

14. In this regard, see the discussion of free banking in Freixas and Rochet (1998, pp. 260-65). 
have centered on the banking sector for substantial involvement. ${ }^{15}$ But nonbanking financial institutions have also received growing attention since the adoption of auditing and disclosure standards by British authorities over 100 years ago and the subsequent growth in securities market activity.

Bank regulation used to be relatively straightforward: authorities simply decided whether or not to grant charters, to limit geographical expansion, to prescribe some activities (such as the holding of government securities), and to proscribe others (such as fraud). Apart from these kinds of regulations, banks were largely self-regulating. But even these relatively few regulations were not always entirely benign. In the United States, for example, banking failures were more widespread in the nineteenth century than in other countries, mainly because of limits on intrastate and interstate branching. ${ }^{16}$ These limits on geographical expansion led to more bank failures than would otherwise have occurred. In effect, this adverse outcome was due to faulty regulation, namely, the restriction on the ability of banks to diversify their loan portfolios geographically. ${ }^{17}$

Bank failures occurred elsewhere, of course, but in those countries in which banks were allowed to branch and belonged to clearinghouses, there was better diversification and greater cooperation in protecting banks against loan losses. This combination provided more appropriate incentives for bankers, and in some cases for private bank supervision (with financial incentives for supervisors), which helped keep failure rates low even during recessions. Moreover, bank failure rates in these types of countries (as in Canada, which allows nationwide branching) were significantly lower than in those with the most restrictive policies on branching. ${ }^{18}$ As Benston and others (1986) point out, moreover, the bank failure rate in the

15. There is disagreement, however, as to whether the central bank, a separate agency, or some combination thereof should regulate and supervise banks.

16. Some states even limited banks to a single office and were known as unit banking states.

17. A Dutch banker's maxim from earlier times was the "watchtower" theory: bankers should lend only as far as they could see from the top of the watchtower in the center of town. The reason is that such loans would be subject to risks that the banker understood. However, the benefits of geographical diversification of lending ultimately proved to outweigh this consideration, as the failure of unit banks seems to indicate. Similarly, a major factor in the U.S. savings and loan debacle was poor regulation in the form of the restriction that institutions fund their long-term, fixed-rate home mortgage loans with shorter-term deposits. Furthermore, restrictions prevented them from hedging the resulting interest rate risk.

18. See Calomiris (1992), Gorton and Mullineaux (1987), and Bordo (1997). 
United States during 1875-1919 was lower than the failure rate for nonfinancial firms.

Yet regardless of the fundamental causes of bank failures, it is unlikely that the view that banking should be largely self-regulated was any more popular in the early 1870 s-when what used to be called the Great Depression began with a financial crisis reminiscent of the East Asian financial crisis in 1997 (see DeLong, 1998) - than in the 1930s, when the entire U.S. banking system collapsed. Indeed, few governments are willing to let the banking system suffer a systemic run, or even to allow any of the largest banks to close. The latter situation gives rise to the "too-big-to-fail" problem. ${ }^{19}$ When a country's banking system suffers a systemic run, or when insolvent banks are allowed to remain open without any overt run, the adverse impact on the economy is substantial. In the case of widespread bank insolvency, even without a run, the credit system typically grinds to a halt, and unprofitable firms are usually able to roll over their loans. The result is a lack of funds for worthwhile investment projects and an inefficient allocation of capital. In the case of widespread bank runs, both the payments system and the credit system collapse, with the economy turning to barter and standards of living plummeting further. ${ }^{20}$ Residents of East Asia, including Japan, discovered the direct and dire consequences of a malfunctioning credit system.

Even proponents of laissez-faire admit that, if they themselves held policymaking positions during a crisis affecting large banks, they most likely would ignore their own advice that no bank is too big to fail. This situation suggests that perhaps one should consider a framework for financial regulation in which one set of rules would operate during normal times, and which would be designed to minimize the likelihood of a financial crisis, and another set of rules would operate when a crisis emerges. Except at the level of generalities (such as Bagehot's rule to discount freely and at a penalty rate), the set of rules governing a crisis would unlikely be specific, so that its effect both on financial sector development and on the occurrence of a financial crisis is problematic.

19. See Baer and Klingebiel (1995) for a discussion of and evidence on the favorable outcomes that result when depositors are allowed to incur losses from bank failures.

20. The payments system may not collapse with insolvent banks remaining open but not experiencing runs. If interbank exposures are covered by implicit or explicit deposit insurance, the payments system will likely continue to function. When interbank exposures are not covered, solvent banks will curtail and avoid exposure to insolvent banks, thereby impeding the efficient operation of the payments system. 
The design of an appropriate regulatory environment during normal times, however, is more tractable. Nevertheless, the issue is certainly not simple. The existence of information asymmetries, coupled with intertemporal transactions, introduces complexities into a financial system. Indeed, without problems of incomplete and imperfect information, a financial system would be easy to regulate because it would be quite trivial. But this is not the case. Banks are therefore quite difficult to regulate: information problems affect all participants, whether they be creditors, shareholders, senior bank managers, or even regulators.

A consensus does appear to be emerging that, because of the inherent difficulty of monitoring financial intermediaries, the regulatory environment needs to change in such a way that there will be several "watchful eyes," that is, participants in the financial marketplace with information about banks available to them and the incentives to act on it. Some countries have already found merit in this approach and operationalized it. Argentina, for example, has increased capital requirements and set a minimum that is tied to indicators of credit and market risk; required banks to issue subordinated debt; strengthened accounting and disclosure requirements; mandated external bank audits; and, more generally, improved supervision. Collectively, these reforms in bank regulation mean that owners, creditors, and supervisors are more likely to monitor banks effectively.

Although the general direction in which many countries need to move with respect to banking reforms is clear, the appropriate mix of all the different components of regulation and supervision is only now becoming a subject of research. For a relatively few countries, some attempts have been made to provide a comparative ranking of selected features of bank regulation. ${ }^{21}$ There is some indication, although necessarily significantly qualified because of limited data availability, that a tighter regulatory environment (that is, one with tougher capital and liquidity standards, stricter definitions of capital and nonperforming loans, more widespread mandatory provisioning once a loan is nonperforming, a greater presence of foreign banks, and a more transparent and better operating environment) will help banking systems survive crises.

Another important aspect of regulation that has received even less attention recently, and which the next section attempts to address, is the allowable activities of banks. For example, do banks that

21. See, for example, Caprio (1998b) and JP Morgan (1997). 
are allowed to engage in financial activities beyond less traditional commercial banking activities-such as securities underwriting and dealing, insurance underwriting and brokerage, real estate investment and development, and ownership and control of nonfinancial firms-intermediate more efficiently, and are they less prone to crisis? The answer is not clear. Proponents of the separation of commercial and investment banking in the United States during the 1930s argued that there are inherent conflicts of interest between the two businesses, notwithstanding the fact that anything other than arm's-length transactions would be bad for business over the long term. Kroszner and Rajan (1994), however, find no empirical evidence to support the view that problems arise from the potential conflict of interest.

Furthermore, White (1986), among others, maintains that universal banks may be better diversified and hence more stable. Yet some bank supervisors argue that combining traditional and nontraditional activities makes banks harder for the regulatory authorities to supervise. In addition, Rajan (1998) suggests that allowing banks to engage in a wide range of activities increases the difficulty of monitoring by market participants. The implication of this view is that harder-to-monitor banks are more likely to pose problems. Indeed, Rajan more generally urges emerging market countries that are considering allowing universal banking to proceed cautiously, while also indicating the need for further empirical research in this area. This paper attempts to begin this research effort by investigating the impact of selected bank regulatory restrictions on various measures of performance. We defer to future research an assessment of the linkages between the broader regulatory environment and the financial sector and, more generally, economic outcomes.

\section{Regulatory Restrictions, Governmental Bureaucracy, and Banking Sector Performance}

This section empirically examines the interrelationships among regulatory restrictions on the activities of banks, the ability of governments and bureaucratic systems to operate effectively, the level of development and efficiency of the banking sector, and the fragility of the banking system. This examination is based upon newly assembled data for a cross section of forty-five countries. The following three questions are addressed: 
- Do countries with relatively weak governmental or bureaucratic systems (measured in terms of corruption, bureaucratic red tape, and the degree to which a country holds to the rule of law) impose harsher regulatory restrictions on the activities of banks (measured in terms of allowable securities activities, insurance activities, real estate activities, and ownership of nonfinancial firms)?

- Do countries with relatively restrictive regulatory systems have poorer functioning banking systems, as measured by deposit money bank credit to the private sector relative to GDP, bank overhead expenditure relative to total assets, and net interest income relative to total assets?

- Do countries with relatively restrictive regulatory systems have lower probabilities of suffering a banking crisis (defined as a situation where the estimated losses from bank failures exceed 5 percent of GDP)?

Cross-country evaluations of national regulatory regimes form the basis for answering all three questions. The first subsection describes our assessment of the restrictiveness of national regulatory systems. The second subsection discusses measures of the strength of governmental and bureaucratic systems. The subsequent subsections report the evidence pertaining to each of the above three questions.

\subsection{Regulatory Restrictions on Bank Activities}

We constructed quantitative data on the allowable nontraditional activities of banks using information from Barth, Nolle, and Rice (1997), Kyei (1995), Akamatsu (1995), the Institute of International Bankers Global Surveys (various years), the Euromoney Banking Yearbook for 1995, and various central bank and government sources. These data form the basis for our assessment of the restrictiveness of national regulatory systems.

The empirical analysis is based upon the degree to which a country's regulatory system allows banks to engage in the following four nontraditional activities:

- SECURITIES: the ability of banks to engage in the businesses of securities underwriting, brokering, dealing, and all aspects of the mutual fund business. 
- INSURANCE: the ability of banks to engage in insurance underwriting and selling

- REAL ESTATE: the ability of banks to engage in real estate investment, development, and management, and

- NONFINANCIAL FIRM OWNERSHIP: the ability of banks to own and control nonfinancial firms.

On the basis of an analysis of available documents, each country's regulations concerning these nontraditional activities have been assessed. These assessments are used to assign a number between 1 and 4 to each of the four activities that indicates the degree of regulatory restrictiveness for that activity in each country. The assigned numbers are interpreted as follows:

$1=$ unrestricted: banks may engage in the full range of the activity directly within the bank

$2=$ permitted: the full range of activities may be conducted, but all or some of the activity must be conducted in subsidiaries

$3=$ restricted: banks may engage in less than the full range of the activity, either in the bank or in subsidiaries, and

$4=$ prohibited: the activity may not be conducted by the bank or by subsidiaries.

The numerical scores assigned to each of the four activities for the countries in our sample are summarized in appendix table A1. A summary index was also computed for the country's overall regulatory restrictiveness toward all four activities. The index, RESTRICT, equals the average of each country's scores for SECURITIES, INSURANCE, REAL ESTATE, and NONFINANCIAL FIRM OWNERSHIP and can therefore take on values between 1 (least restrictive) and 4 (most restrictive). The average value of RESTRICT is 2.2 , with a standard deviation of 0.6 . Five countries have very restrictive regulatory systems (RESTRICT > 3): Chile, Ecuador, Indonesia, Japan, and Peru. Six countries have very permissive systems (RESTRICT $<$ 1.5): Austria, Israel, Malaysia, Sri Lanka, Switzerland, and the United Kingdom. The United States has a value of 3.

These data on regulatory restrictiveness clearly involve some degree of subjectivity. As more detailed and comprehensive information becomes available, we will therefore update the data and the results that follow. Nonetheless, the currently available data and the 
approach taken provide new and useful-although certainly not unassailable-information regarding the interrelationships among regulatory regimes, governmental and bureaucratic systems, banking sector development, and especially banking sector fragility.

\subsection{Governmental and Bureaucratic Systems}

Information about the effectiveness of governmental and bureaucratic systems is used for two reasons. First, the paper seeks to assess the relationship between the quality of the governmental bureaucracy and the restrictiveness of the regulatory regime. To perform such an assessment, one needs quantitative measures regarding the manner in which the government operates. Second, the paper seeks to assess the relationship between the restrictiveness of the regulatory regime and both banking sector development and the fragility of the banking system. To make this assessment, one needs to control for other factors. Specifically, one needs to control for the overall effectiveness of the governmental and bureaucratic system, to determine the extent to which there is an independent link between a country's regulatory restrictiveness, on one hand, and its banking sector development and the fragility of its banking system, on the other. For these reasons measures of the way in which a governmental and bureaucratic system functions are used in conducting our analyses.

Numerous measures of the functioning of the government were considered, but the focus is on the following three:

- REDTAPE, which represents an assessment of the degree to which the governmental bureaucracy is an obstacle to business. Higher values of REDTAPE represent less red tape and a more smoothly functioning bureaucracy. ${ }^{22}$ REDTAPE takes on values between 1 and 10 .

- CORRUPT, which represents an assessment of corruption in government. Higher values of CORRUPT indicate that high government officials are less likely to demand special payments for performing various services and signify that illegal payments are generally less common throughout government. CORRUPT takes on values between 1 and 10 .

22. Data for REDTAPE are obtained from the Business International Corporation and cover the early 1980s. For more information see Mauro (1995). 
- RULELAW, which represents an assessment of the law and order tradition in the country as determined by the International Country Risk Guide. Higher values of RULELAW indicate that a country adheres to the rule of law to a greater degree than countries with lower values. RULELAW takes on values between 1 and $10 .^{23}$

In addition, we consider GOVERNMENT, which is a composite index of the quality of the governmental and bureaucratic system and equals the average value of REDTAPE, CORRUPT, and RULELAW. This means that higher values of GOVERNMENT indicate better-functioning governments. The average value of GOVERNMENT for the countries in our sample is 7.0, with a standard deviation of 2.3. Three countries have values of 10 for GOVERNMENT: the Netherlands, New Zealand, and Switzerland. The United States has a value of 9.3, and Chile has a value of 7.2. Six countries have values below 4 , indicating very poor governmental and bureaucratic systems: Colombia, Egypt, Indonesia, Nigeria, Pakistan, and the Philippines. Other measures of the governmental and bureaucratic system were considered, including assessments of the risk of government repudiation of contracts, assessments of the risk of government expropriation of private property, and assessments of the efficiency of the judiciary system. Incorporating these alternative indicators into the analyses does not change any of the results that follow, however.

\subsection{Regulatory Restrictiveness and Quality of the Governmental and Bureaucratic System}

This subsection addresses the first question above: Do countries with relatively weak governmental and bureaucratic systems impose harsher regulatory restrictions on the activities of banks?

Table 1 shows that countries with better government systems (higher values of GOVERNMENT) on average have less restrictive regulatory systems (lower values of RESTRICT). The negative relationship between better government and regulatory restrictions is strongest for REAL ESTATE and NONFINANCIAL FIRM

23. Data for CORRUPT and RULELAW cover the period 1982-95 and are taken from LaPorta and others (1998), who obtained the data from the International Country Risk Guide. 
Table 1. Evidence on the Relationship between Regulatory Restrictiveness and the Quality of Governmental and Bureaucratic Systems ${ }^{\mathrm{a}}$

\begin{tabular}{lccccc}
\hline Variable & & & REAL & NONFINANCIAL \\
\hline Simple correlations & RESTRICT $^{b}$ & SECURITIES & INSURANCE & ESTATE & FIRMOWNERSHIP \\
Government $^{c}$ & & & & & \\
& -0.436 & -0.220 & -0.207 & -0.364 & -0.449 \\
Regressions & $(0.004)$ & $(0.140)$ & $(0.144)$ & $(0.037)$ & $(0.007)$ \\
Constant & & & & & \\
& 3.778 & 0.977 & 7.468 & 3.622 & 2.323 \\
ECONOMIC & $(0.006)$ & $(0.579)$ & $(0.000)$ & $(0.052)$ & $(0.322)$ \\
DEVELOPMENT & -0.044 & 0.215 & -0.638 & 0.047 & 0.317 \\
REVOLUTION & $(0.813)$ & $(0.430)$ & $(0.020)$ & $(0.853)$ & $(0.379)$ \\
ANDCOUPS & -1.009 & -0.674 & -0.840 & -1.376 & -1.420 \\
GOVERNMENT & $(0.001)$ & $(0.023)$ & $(0.014)$ & $(0.013)$ & $(0.011)$ \\
& -0.156 & -0.162 & 0.078 & -0.206 & -0.370 \\
Summary statistic & $(0.008)$ & $(0.083)$ & $(0.323)$ & $(0.008)$ & $(0.007)$ \\
$R^{2}$ & 0.33 & 0.12 & 0.18 & 0.23 & 0.29 \\
P value (F statistic) & 0.00 & 0.17 & 0.05 & 0.01 & 0.00 \\
\hline
\end{tabular}

Source: Authors' calculations.

a. Numbers in parentheses are $\mathrm{p}$ values. Variables not defined below are defined in the text.

b. Average of SECURITIES, INSURANCE, REAL ESTATE, and NONFINANCIAL FIRM OWNERSHIP.

c. Average of REDTAPE, CORRUPT, and RULELAW.

OWNERSHIP. ${ }^{24}$ Table 1 also shows that these findings remain unchanged even after controlling both for the level of economic development and for political stability. ${ }^{25}$ Thus countries with better-functioning governments-less red tape, less corruption, and a stronger rule of law-on average allow banks the opportunity to provide their customers a wider array of nontraditional services. ${ }^{26}$

These findings suggest that it is possible to substitute among different government mechanisms for overseeing bank behavior. This is consistent with recent work on legal systems. LaPorta and others (1998), for instance, find that countries with legal systems that impede minority shareholders from exerting their rights are more likely to introduce mandatory dividends. Our findings indicate that countries with weak governments-that is, governments

24. We also examined accounting standards. The correlation between accounting standards and regulatory restrictiveness is -0.44 , with a $p$ value of 0.005 , and the relationship remains significant at the 1 percent level after controlling for GDP per capita and measures of political stability.

25. To measure the level of economic development, the logarithm of real GDP per capita is used. Political instability is a measure of revolutions and coups, obtained from Banks (1994).

26. These results also hold for the individual components of GOVERNMENT. 
that are less likely to supervise banks approximately or to create proper incentives for private sector participants to supervise banks-also on average impose harsher restrictions on the activities of banks. ${ }^{27}$ Of course, a third factor may be responsible for both effects. Political constraints, for instance, may prevent a government from both improving the operation of the bureaucracy and relaxing regulatory restrictions on the activities of banks.

\subsection{Regulatory Restrictiveness and Banking Sector Development and Efficiency}

This subsection addresses the second question: Do countries with more restrictive regulatory systems have poorer-functioning banking systems, as measured by deposit money bank credit to the private sector relative to GDP, bank overhead expenditures relative to total assets, and net interest income relative to total assets?

To assess the relationship between regulatory restrictiveness and banking sector development and efficiency, the following commonly employed measures of the latter variables are used:

- PRIVATE CREDIT, which is deposit money bank credit to the private sector relative to GDP

- OVERHEAD, which is bank overhead expenditures relative to total assets, and

- NET INTEREST, which is net interest income relative to total assets. $^{28}$

Levine (1998) and Levine, Loayza, and Beck (2000) find that PRIVATE CREDIT exerts a causal and positive impact on long-run economic growth. Demirgüç-Kunt, Levine, and Min (1998) find that OVERHEAD is also closely associated with more rapid economic growth in a broad cross section of countries. Many researchers, moreover, use various indicators of interest rate margins, such as NET INTEREST, to assess banking sector efficiency. ${ }^{29}$

27. We collected more detailed information on supervisory systems, which is permitting a more precise evaluation of this hypothesis. See Barth, Caprio, and Levine (2001a, b, c).

28. PRIVATE CREDIT is from Levine, Loayza, and Beck (2000). It is an average over the period 1980-95. See also Levine (1998). OVERHEAD and NET INTEREST are from Demirgüç-Kunt, Levine, and Min (1998). The underlying data stem from individual financial statements provided by BankScope and are averaged over the period 1985-95.

29. See, for example, Demirgüç-Kunt and Huizinga (1999). 


\section{Table 2. Evidence on the Relationship between Regulatory Restrictiveness and Banking Sector Development ${ }^{a}$}

\begin{tabular}{lccc}
\hline Variable & PRIVATE CREDIT & OVERHEAD & NET INTEREST \\
\hline Simple correlations & & & \\
RESTRICT & -0.37 & 0.24 & 0.31 \\
SECURITIES & $(0.008)$ & $(0.131)$ & $(0.020)$ \\
& -0.21 & 0.24 & 0.21 \\
INSURANCE & $(0.169)$ & $(0.095)$ & $(0.105)$ \\
& -0.10 & -0.06 & -0.05 \\
REALESTATE & $(0.258)$ & $(0.869)$ & $(0.908)$ \\
& -0.34 & 0.17 & 0.32 \\
NONFINANCIALFIRM & $(0.012)$ & $(0.153)$ & $(0.009)$ \\
OWNERSHIP & -0.41 & 0.33 & 0.38 \\
& $(0.017)$ & $(0.038)$ & $(0.006)$ \\
Regressions & & & \\
Constant & -58.44 & -0.84 & 1.01 \\
& $(0.333)$ & $(0.898)$ & $(0.827)$ \\
ECONOMICDEVELOPMENT & 15.44 & 0.16 & -0.04 \\
& $(0.007)$ & $(0.802)$ & $(0.921)$ \\
REVOLUTIONAND COUPS & -14.47 & 2.91 & 1.62 \\
& $(0.195)$ & $(0.180)$ & $(0.172)$ \\
RESTRICT & -11.66 & 1.26 & 1.22 \\
Summary statistic & $(0.196)$ & $(0.106)$ & $(0.023)$ \\
$R^{2}$ & & & \\
P value (F statistic) & 0.38 & 0.13 & 0.17 \\
\hline
\end{tabular}

Source: Authors' calculations.

a. Numbers in parentheses are p values. Variables are as defined in table 1 and in the text.

Table 2 presents mixed results regarding the relationship between the degree of regulatory restrictiveness and banking sector development and efficiency. Although countries with more restrictive regulations on average have less bank credit, greater overhead expenditures, and greater net interest income, the correlations are not very robust. For instance, even though RESTRICT and PRIVATE CREDIT are significantly negatively correlated, this relationship breaks down when one controls for the level of economic development and political stability. Similarly, of the regulatory restrictiveness indicators, OVERHEAD is significantly correlated only with NONFINANCIAL FIRM OWNERSHIP, but even this relationship becomes insignificant when one controls for the level of economic development and political stability. Greater regulatory restrictiveness does remain positively correlated with NET INTEREST, however, even when one controls for these other factors. Yet this result mainly runs through REAL ESTATE and NONFINANCIAL FIRM 
OWNERSHIP. The finding may therefore be simply due to the fact that harsher restrictions on real estate and nonfinancial firm ownership cause total assets of the banking sector to be less than otherwise, thereby increasing NET INTEREST. The relationship may, in other words, have nothing to do with interest rate spreads per se. ${ }^{30}$ Thus this preliminary analysis suggests that there is not a reliable and direct link between the degree of regulatory restrictiveness and widely used measures of banking sector development and efficiency. For recent extensions, see Barth, Caprio, and Levine (2001b).

\subsection{Regulatory Restrictiveness and Banking Crises}

This subsection addresses the third question: Do countries with more restrictive regulatory systems have a lower probability of suffering a banking crisis?

To assess the impact of regulatory restrictiveness on banking sector fragility, two measures of whether a country's banking system has suffered a crisis during the last fifteen years are used. First, a country is considered to have experienced a crisis when the estimated losses to the government due to banking sector problems exceeded 5 percent of GDP. Second, to provide a more general indicator of fragility, a country is considered to have experienced a crisis when the banking system is judged to be insolvent, even if eventual losses are less than 5 percent of GDP. Since both indicators produce similar results, only results based upon the first measure are reported here; that is, a country is considered to have experienced a crisis only when the estimated losses were greater than 5 percent of GDP.

The empirical results indicate a positive relationship between the degree of regulatory restrictiveness-especially restrictions on the securities activities of banks - and banking sector fragility. The relationships between banking crises and both the governmental and bureaucratic system and the regulatory environment are examined using both simple correlations and probit regressions. Table 3 presents the results based on the correlations. A positive link is seen between banking sector crises and the stringency of restrictions on banks' activities in the securities market business. Also, there is a significantly negative correlation between banking sector crises and good governmental and bureaucratic systems.

30. Unfortunately, the BankScope data available to us do not include interest rate spreads, but only interest income and interest expenses. 


\section{Table 3. Evidence on the Relationship among Banking Crises, Governmental and Bureaucratic Systems, and Regulatory Restrictiveness ${ }^{a}$}

\begin{tabular}{lccccccc}
\hline & & & & & & \multicolumn{3}{c}{$\begin{array}{c}\text { NONFINANCIAL } \\
\text { Variable }\end{array}$} & GOVERNMENT & CRISIS $^{b}$ & RESTRICT & SECURITES & INSURANCE & $\begin{array}{c}\text { REAL } \\
\text { ESTATE }\end{array}$ & FWNERSHIP \\
\hline Correlations & & & & & & & \\
CRISIS & -0.37 & $\ldots$ & 0.30 & 0.39 & -0.07 & 0.30 & 0.29 \\
& $(0.016)$ & $\ldots$ & $(0.047)$ & $(0.009)$ & $(0.872)$ & $(0.065)$ & $(0.089)$ \\
& & & & & & & \\
Quartile grouping by governmental and bureaucratic system & & & & \\
Very poor government & $\ldots$ & 0.62 & 2.33 & 1.82 & 2.73 & 2.58 & 2.18 \\
Poor government & $\ldots$ & 0.33 & 2.12 & 1.80 & 2.20 & 2.80 & 1.67 \\
Good government & $\ldots$ & 0.33 & 1.89 & 1.27 & 2.45 & 2.09 & 1.73 \\
Very good government & $\ldots$ & 0.17 & 1.98 & 1.58 & 2.17 & 2.25 & 1.92 \\
Quartile grouping by regulatory permissiveness & & & & & & \\
Very restrictive & 5.92 & 0.63 & $\ldots$ & $\ldots$ & $\ldots$ & $\ldots$ & $\ldots$ \\
Restrictive & 5.19 & 0.56 & $\ldots$ & $\ldots$ & $\ldots$ & $\ldots$ & $\ldots$ \\
Permissive & 7.71 & 0.25 & $\ldots$ & $\ldots$ & $\ldots$ & $\ldots$ & $\ldots$ \\
Very permissive & 7.68 & 0.25 & $\ldots$ & $\ldots$ & $\ldots$ & $\ldots$ & $\ldots$ \\
\hline
\end{tabular}

Source: Authors' calculations.

a. Numbers in parentheses are $\mathrm{p}$ values.

b. Equals 1 when the estimated cost of a banking crisis is greater than 5 percent of GDP, and 0 otherwise. Sample size is eighteen countries.

The empirical results based upon the probit regressions support the contention that countries restricting the securities activities of banks have a significantly higher probability of suffering a banking crisis than do countries that allow banks greater freedom to engage in these activities. Table 4 presents the results based on the probit regressions. The dependent variable is a dummy variable called CRISIS, which equals 1 if a country has suffered a banking crisis and 0 otherwise.

In the probit regressions, a wide array of control variables are included to more accurately assess whether there is an independent link between banking crises and the degree of regulatory restrictiveness on the activities of banks. In particular, we control for the quality of both the governmental and bureaucratic system and accounting standards, since a close connection is observed among poor government systems, poor accounting standards, and harsher regulatory restrictiveness. Importantly, a significant link is found between the harshness of bank securities restrictions and the likelihood of a banking crisis, even after controlling for these institutional 
Table 4. Explaining the Likelihood of Banking Crises: Probit Regressions with Bank Securities Restrictions and Bank Composite Regulatory Restrictions ${ }^{a}$

\begin{tabular}{lcc}
\hline Other explanatory variables & $\begin{array}{c}\text { Coefficient on } \\
\text { SECURITIES }\end{array}$ & $\begin{array}{c}\text { Coefficient on } \\
\text { RESTRICT }\end{array}$ \\
\hline Constant only & 0.79 & 0.88 \\
& $(0.019)$ & $(0.015)$ \\
Constant, GOVERNMENT, ACCOUNT & 0.87 & 0.86 \\
& $(0.024)$ & $(0.051)$ \\
Constant, GOVERNMENT, ACCOUNT, & 1.05 & 0.96 \\
CREDITOR AND SHAREHOLDER RIGHTS & $(0.015)$ & $(0.043)$ \\
Constant, GOVERNMENT, ACCOUNT, & 1.02 & 1.05 \\
CREDITOR AND SHAREHOLDER RIGHTS, & $(0.021)$ & $(0.041)$ \\
PRIVATE CREDIT, INITIAL INCOME, & & \\
GROWTH & & \\
\hline
\end{tabular}

Source: Authors' calculations.

a. The dependent variable is CRISIS, which is defined as in table 3. Numbers in parentheses are $p$ values. ACCOUNT is a measure of accounting standards, INITIAL INCOME is based on GDP per capita, and GROWTH is a measure of the recent economic growth rate.

factors. We also control for the degree to which legal codes emphasize the rights of secured creditors and minority shareholders, since the contracting environment may influence the incentives facing bank managers and pressures for regulatory intervention. Even after controlling for these legal characteristics, however, the findings still indicate that greater restrictions on the securities activities of banks produce a significantly higher probability of a banking crisis.

As an additional check on the robustness of this finding, we control for the overall level of economic development and the development of the financial system by including measures of the level of GDP per capita, the recent economic growth rate, and the size of the banking system. After controlling for these economic and financial development indicators, the legal characteristics, and the institutional variables, the results still indicate that countries that restrict the securities activities of banks have a significantly higher probability of suffering a banking crisis than do countries with less restrictive regulatory practices. Furthermore, an attempt was made to control for bank franchise value by including measures of the net interest income of banks (NET INTEREST MARGIN) and the concentration of the banking sector, which equals the percentage of total banking system assets accounted for by the five largest banks. Again, the findings remain unchanged: a positive and statistically significant 
relationship exists between the harshness of restrictions on the securities activities of banks and a banking sector crisis. ${ }^{31}$

There may be concerns about endogeneity. Countries with a fragile banking system may adopt restrictive banking sector regulations. Thus the probit results in table 4 may suffer from simultaneity bias. To control for this bias, we use a two-step instrumental variables estimator. ${ }^{32}$ We tried a number of different instrumental variables. Here we report the results using the legal origin of each country as an instrumental variable for regulatory restrictiveness. Legal scholars have shown that much of the world can be divided into countries with either an English, French, German, or Scandinavian legal heritage. Since a country's legal heritage was determined far in the past and was frequently driven by colonization and conquest, we can treat legal heritage as exogenous to whether the country has experienced a banking crisis recently. Moreover, the origin of a country's legal system has a profound effect on the specific laws, regulations, and enforcement mechanisms that govern financial sector activities (LaPorta and others, 1998). Thus we use an instrumental variables probit estimator to gauge the causal impact of regulatory restrictiveness on banking sector fragility.

The results in table 5 indicate that simultaneity bias is not driving the positive relationship between restrictions on banks engaging in securities market activities and banking sector fragility. That is, the finding remains that when banks face greater restrictions on their ability to engage in securities market activities, they have a higher probability of suffering a banking crisis. Although the data provide less confident results on bank restrictiveness in general, they are consistent with the view that lowering restrictions on the securities market activities of banks will boost rather than jeopardize banking sector stability.

The relationship between regulatory restrictions on the activities of banks and banking system crises, moreover, is economically quite large. The coefficient estimates suggest that a rise in restrictiveness by 1 index unit (for example, the characterization of

31. We also included a dummy variable indicating whether a country has an explicit deposit insurance scheme, since Demirgüç-Kunt and Detragiache (1997, 1998) find that deposit insurance regimes are positively associated with banking crises. The inclusion of this variable does not change our findings regarding regulatory restrictions on bank securities activities.

32. The instrumental variables estimator is analogous to the two-stage least squares, except that it must be appropriately modified to a limited dependent variable framework. This is described in Maddala (1983). 
Table 5. Explaining the Likelihood of Banking Crises: Instrumental Variables Regressions with Bank Securities Restrictions and Bank Composite Regulatory Restrictions ${ }^{a}$

\begin{tabular}{lcc}
\hline Other explanatory variables & $\begin{array}{c}\text { Coefficient on } \\
\text { SECURITIES }\end{array}$ & $\begin{array}{c}\text { Coefficient on } \\
\text { RESTRICT }\end{array}$ \\
\hline Constant only & 0.86 & 0.52 \\
& $(0.014)$ & $(0.117)$ \\
Constant, GOVERNMENT, ACCOUNT & 1.04 & 0.84 \\
& $(0.010)$ & $(0.056)$ \\
Constant, GOVERNMENT, ACCOUNT, & 1.24 & 1.05 \\
CREDITOR AND SHAREHOLDER RIGHTS & $(0.008)$ & $(0.035)$ \\
Constant, GOVERNMENT, ACCOUNT, & 1.24 & 1.48 \\
CREDITOR AND SHAREHOLDER RIGHTS, & $(0.013)$ & $(0.027)$ \\
PRIVATE CREDIT, INITIAL INCOME, & & \\
GROWTH & & \\
\hline
\end{tabular}

Source: Authors' calculations

a. A variable indicating the origin of the legal system (English, French, German, or Scandinavian) was used as the instrument for the regulatory restrictiveness variables. Other variables in the conditioning information set are treated as exogenous. The dependent variable is CRISIS, which is defined as in table 3 . Numbers in parentheses are $\mathrm{p}$ values.

regulation on banks' securities activities changes from "permitted" to "restricted") increases the probability of a banking crisis by between 25 and 33 percentage points, depending on the specific control variables included. (This particular evaluation is based upon the mean values of the variables in the regression equation. $)^{33}$ Thus, in addition to being statistically significant, the empirical results suggest that restricting the ability of banks to diversify their activities influences their fragility in an economically important manner.

The finding that restrictions on the securities activities of banks on average significantly increase the likelihood of banking sector fragility is consistent with evaluations of events during the Great Depression in the United States. White (1983, 1986), for example, shows that banks that were engaged in investment banking activities during the 1930s were better diversified and thus less likely to fail than banks that were not involved in the securities market business. ${ }^{34}$

33. Since the probit technique is a nonlinear estimation procedure, the implied effect of a given change in SECURITIES on the probability of a crisis is nonlinear and depends on the precise characteristics of the individual country involved in the conceptual experiment.

34. Note that in the United States in the period before the enactment of the Glass-Steagall Act, big banks were most likely to be involved in investment banking activities. This confounds some of White's $(1983,1986)$ analyses. In our study, however, we study the whole regulatory regime, which reduces this complication. Also see Kroszner and Rajan (1994) and Rajan (1998). 
Although more research surely is needed, these results suggest that, even after controlling for many relevant features of national economies, allowing banks greater freedom to engage in securities activities reduces the likelihood of banking crises.

\section{Directions for Future Research}

A more extensive data set, in terms of both the variables included and the range of countries, will enable us to provide better information and thus better advice on appropriate regulatory reforms. For example, our finding that banks with more diversified powers are less likely to suffer a banking crisis may be sensitive to other components of the regulatory environment, which for now are omitted variables in our analysis. It may be that countries that allow broader powers to banks, for example, also have higher capital requirements or better supervision. Or it may be that they are the countries that have more foreign banks, which may well be better at risk management. One should also consider the organizational structure of banks that engage in a wider range of activities. Whether the activities are conducted within the bank itself or through subsidiaries or affiliates may matter. More generally, it seems increasingly clear that the new global and technological environment requires regulation and supervision that focuses on the performance of the financial system as a whole. One should therefore consider the extent to which regulations directed at one specific component of a country's financial system spill over to other components as well as to the financial systems of other countries. In any event, in order to increase the robustness of any policy recommendations, these types of extensions are important and will be the subject of future research. See Barth, Caprio, and Levine (2001a, b, c). 


\section{APPENDIX}

Table A1. Quantitative Measures of Regulatory Restrictiveness for the Countries in the Sample

\begin{tabular}{|c|c|c|c|c|c|}
\hline Country & SECURITIES & INSURANCE & $\begin{array}{c}\text { REAL } \\
\text { ESTATE }\end{array}$ & $\begin{array}{l}\text { NONFINANCIAL } \\
\text { FIRMOWNERSHIP }\end{array}$ & RESTRICT \\
\hline Argentina & 3 & 2 & 2 & 3 & 2.50 \\
\hline Australia & 1 & 2 & 3 & 2 & 2.00 \\
\hline Austria & 1 & 2 & 1 & 1 & 1.25 \\
\hline Belgium & 2 & 2 & 3 & 3 & 2.50 \\
\hline Brazil & 2 & 2 & 3 & 3 & 2.50 \\
\hline Canada & 2 & 2 & 2 & 3 & 2.25 \\
\hline Chile & 2 & 3 & 4 & 4 & 3.25 \\
\hline Colombia & 2 & 2 & 2 & 4 & 2.50 \\
\hline Denmark & 1 & 2 & 2 & 2 & 1.75 \\
\hline Ecuador & 2 & 4 & 4 & n.a. & 3.33 \\
\hline Egypt, Arab Rep. & 2 & 2 & 3 & 3 & 2.50 \\
\hline Finland & 1 & 3 & 2 & 1 & 1.75 \\
\hline France & 1 & 2 & 2 & 1 & 1.50 \\
\hline Germany & 1 & 3 & 2 & 1 & 1.75 \\
\hline Greece & 2 & 3 & 3 & 1 & 2.25 \\
\hline HongKong(China) & 1 & 2 & 2 & 3 & 2.00 \\
\hline India & 2 & 4 & 3 & 3 & 3.00 \\
\hline Indonesia & 2 & 4 & 4 & 4 & 3.50 \\
\hline Ireland & 1 & 4 & 1 & 1 & 1.75 \\
\hline Israel & 1 & 1 & 1 & 1 & 1.00 \\
\hline Italy & 1 & 2 & 3 & 3 & 2.25 \\
\hline Japan & 3 & 4 & 3 & 3 & 3.25 \\
\hline Korea, Rep. of & 2 & 2 & 2 & 3 & 2.25 \\
\hline Malaysia & 1 & 1 & 1 & 2 & 1.25 \\
\hline Mexioo & 2 & 2 & 3 & 4 & 2.75 \\
\hline Netherlands & 1 & 2 & 2 & 1 & 1.50 \\
\hline NewZealand & 2 & 2 & 2 & 1 & 1.75 \\
\hline Nigeria & 1 & 2 & 2 & 2 & 1.75 \\
\hline Norway & 2 & 2 & 2 & 2 & 2.00 \\
\hline Pakistan & 2 & 4 & 3 & 2 & 2.75 \\
\hline Peru & 2 & 4 & 3 & 4 & 3.25 \\
\hline Philippines & 1 & 2 & 2 & 2 & 1.75 \\
\hline Portugal & 1 & 2 & 3 & 2 & 2.00 \\
\hline Singapore & 2 & 2 & 2 & 3 & 2.25 \\
\hline SouthAfrica & 1 & 2 & 3 & 2 & 2.00 \\
\hline Spain & 1 & 2 & 3 & 1 & 1.75 \\
\hline SriLanka & & & 1 & 1 & 1.00 \\
\hline Sweden & 1 & 2 & 3 & 3 & 2.25 \\
\hline Switzerland & 1 & 2 & 1 & 1 & 1.25 \\
\hline Thailand & 2 & 2 & 2 & 3 & 2.25 \\
\hline Turkey & 1 & 2 & 4 & 3 & 2.50 \\
\hline United Kingdom & 1 & 2 & 1 & 1 & 1.25 \\
\hline United States & 3 & 3 & 3 & 3 & 3.00 \\
\hline Uruguay & 3 & 2 & 3 & 4 & 3.00 \\
\hline Venezuela & 2 & 2 & 3 & 3 & 2.50 \\
\hline
\end{tabular}

Source: Authors' calculations based on Barth, Nolle, and Rice (1997), Kyei (1995), Akamatsu (1995), Institute of International Bankers Global Survey (various years), Euromoney Banking Yearbook 1995, and various central bank and government sources. 


\section{REFERENCES}

Akamatsu, N. 1995. "Enterprise Governance and Investment Funds in Russian Privatization." In Corporate Governance in Transitional Economies: Insider Control and the Role of Banks, edited by M. Aoki and H. Kim. Washington: World Bank.

Baer, H., and D. Klingebiel. 1995. "Systemic Risk When Depositors Bear Losses: Five Case Studies." In Banking, Financial Markets, and Systemic Risk, edited by G. Kaufman. Greenwich, Conn.: JAI Press.

Bank for International Settlements. 1998. Reports on the International Financial Architecture. Basel (www.bis.org/publothp01.htm).

Banks, A. 1994. Cross-National Time Series Data Archive. Binghampton, N.Y.: Center for Social Analysis, State University of New York at Binghampton.

Barth, J. R. 1996. The Great Savings and Loan Debacle. Washington: AEI Press.

Barth, J. R., R. D. Brumbaugh, Jr., L. Ramesh, and G. Yago. 1998. "The Role of Governments and Markets in International Banking Crises: The Case of East Asia." In Research in Financial Services, edited by G. Kaufman. Greenwich, Conn.: JAI Press.

Barth, J. R., R. D. Brumbaugh, Jr., and G. Yago. 1997. "Breaching the Walls Between Banking and Commerce." Banking Strategies (July/August): 47-52.

Barth, J. R., G. Caprio, and R. Levine. 2001a. "Banking Systems Around the Globe: Do Regulations and Ownership Affect Performance and Stability?" In Prudential Supervision What Work and What Doesn't, edited by F. S. Mishkin. Chicago: University of Chicago Press.

. 2001b. "Bank Regulation and Supervision: What Works Best? Unpublished Paper. Washington: World Bank.

- 2001c. "The Regulation and Supervision of Banks Around the World: A New Database." In Integrating Emerging Market Countries into the Global Financial System, edited by R. E. Litan and R. Herring. Brookings-Wharton Papers on Financial Services. Washington: The Brookings Institution Press.

Barth, J. R., D. E. Nolle, and T. N. Rice. 1997. "Commercial Banking Structure, Regulation and Performance: An International Comparison." Economics Working Paper 97-6. Washington: Office of the Comptroller of the Currency, U.S. Treasury Department (March). 
Benston, G., R. Eisenbeis, P. Horvitz, E. J. Kane, and G. Kaufman. 1986. Perspectives on Safe and Sound Banking: Past, Present and Future. Washington and Cambridge, Mass.: American Bankers Association in cooperation with MIT Press.

Bordo, M. 1997. "Regulation and Bank Stability: Canada and the United States, 1870-1980." In Reforming Financial Systems: Historical Implications for Policy, edited by G. Caprio, Jr., and D.Vittas. New York and London: Cambridge University Press.

Calomiris, C. 1992. "Regulation, Industrial Structure, and Instability in U.S. Banking: An Historical Perspective." In Structural Change in Banking, edited by M. Klausner and L. White. Homewood, Ill.: Irwin.

Caprio, G. 1998a. "Bank Insolvencies: Cross-Country Experience." Research Working Paper 1620. Washington: World Bank (July). . 1998b. "Banking on Crises: Expensive Lessons." Paper presented at the Western Economics Association meetings (June).

Caprio, G., and B. Wilson. 1997. "On Not Putting All the Eggs in One Basket: The Role of Diversification in Banking." Paper presented at the World Bank-IMF Annual Meetings (September).

Caprio, G., and D. Klingebiel. 1997. "Bank Insolvency: Bad Luck, Bad Policy, and Bad Banking." In Annual Bank Conference on Development Economics 1996, edited by M. Bruno and B. Pleskovic. Washington: World Bank.

Caprio, G., I. Atiyas, and J. Hanson. 1994. Financial Reform: Theory and Experience, chapter 13. New York and London: Cambridge University Press.

DeLong, J. B. 1998. "Asia's Flu: A History Lesson." Unpublished paper. University of California, Berkeley (econ161.berkeley. $\mathrm{edu} /$ ).

Demirgüç-Kunt, A., and E. Detragiache. 1997. "The Determinants of Banking Crises: Evidence from Developing and Developed Countries." IMF Working Paper 106. Washington: International Monetary Fund.

- 1998. "Financial Liberalization and Financial Fragility." IMF Working Paper 83. Washington: International Monetary Fund (June).

Demirgüç-Kunt, A., and H. Huizinga. 1999. "Determinants of Commercial Bank Interest Margins and Profitability: Some International Evidence." World Bank Economic Review 13(2): 379-408. 
Demirgüç-Kunt, A., R. Levine, and H. Min. 1998. "Foreign Banks: Efficiency, Stability, and Growth." In The Implications of Globalization of World Financial Markets, edited by S. Lee. Seoul: Bank of Korea.

Freixas, X., and J. Rochet. 1998. Microeconomics of Banking. Cambridge, Mass.: MIT Press.

García, G., C. J. Lindgren, and M. I. Saal. 1996. Bank Soundness and Macroeconomic Policy. Washington: International Monetary Fund. Goldstein, M.. 1998. The Asian Financial Crisis: Causes, Cures, and Systemic Implications. Washington: Institute for International Economics.

Goldstein, M., and P. Turner. 1996. "Banking Crises in Emerging Economies: Origins and Policy Options." BIS Economic Papers 46. Basle, Switzerland: Bank for International Settlements (October).

Gorton, G. and D. Mullineaux. 1987. "The Joint Production of Confidence: Endogenous Regulation and Nineteenth Century Commercial-Bank Clearinghouses." Journal of Money, Credit, and Banking 19(4): 457-68.

Hellmann, T., K. Murdoch, and J. Stiglitz. 1998. "Liberalization, Moral Hazard in Banking, and Prudential Regulation: Are Capital Requirements Enough?" Unpublished paper. Stanford University.

JP Morgan. 1997. "Latin American Banks: How Conservative Regulations Help Create Profits." JP Morgan Equity Research (January 22).

Kroszner, R. S., and R. G. Rajan. 1994. "Is the Glass-Steagall Act Justified? A Study of the U.S. Experience with Universal Banking Before 1933." American Economic Review 84(4): 810-32.

Kyei, A. 1995. "Deposit Protection Arrangements: A Survey." IMF Working Paper. Washington: International Monetary Fund (December).

La Porta, R., F. Lopez-de-Silanes, A. Shleifer, and R. W. Vishny. 1997. "Legal Determinants of External Finance." Journal of Finance 52(3): 1131-50. Economy106(6): 1113-55.

Levine, R. 1998. "The Legal Environment, Banks, and Long-Run Economic Growth." Journal of Money, Credit, and Banking 30(3, part 2): 596-613.

Levine, R., N. Loayza, and T. Beck. 2000. "Financial Intermediation and Growth: Causality and Causes." Journal of Monetary Economics: 46(1): 31-77. 
Maddala, G. S. 1983. Limited Dependent and Qualitative Variables in Economics. New York: Cambridge University Press.

Mauro, P. 1995. "Corruption and Growth."Quarterly Journal of Economics 105(3): 681-712.

Puri, M. 1996. "Commercial Banks in Investment Banking: Conflict of Interest or Certification Role?" Journal of Financial Economics (March): 373-401.

Radelet, S., and Jeffrey D. Sachs. 1998. "The East Asian Financial Crisis: Diagnosis, Remedies, Prospects." Brookings Papers on Economic Activity 1: 1-74.

Rajan, R. 1998. "An Investigation into the Economics of Extending Bank Powers.” Unpublished paper. Graduate School of Business, University of Chicago.

White, E. 1983. The Regulation and Reform of the American Banking System. Princeton, N.J.: Princeton University Press.

1986. "Before the Glass-Steagall Act: An Analysis of the Investment Banking Activities of National Banks." Explorations in Economic History 23(1): 33-55. 
